\title{
The eggshell morphology of Heterodoxus spiniger, infesting dog, Canis familiaris (Boopidae, Mallophaga)
}

\author{
Sanjita Tyagi ${ }^{2}$, Nidhi Gupta ${ }^{1}$, V. D. Joshi ${ }^{2}$, Archna Rashmi ${ }^{1}$, Gaurav Arya ${ }^{1}$ and A. K. Saxena ${ }^{1 *}$ \\ ${ }^{1}$ Department of Zoology, Government Raza Postgraduate College, Rampur - 244901 (U.P.), INDIA \\ ${ }^{2}$ Department of Zoology, Government P. G. College, Kotdwara (Uttarakhand), INDIA \\ *Corresponding author.E-mail: akscsir@ rediffmail.com
}

\begin{abstract}
The egg chorion of the dog louse Heterodoxus spiniger bears pentagonal / rectangular scutes (scale like sculpturing) arranged obliquely. The opercular disc of the egg bears tall cup shaped micropyles which unite to give ridge like appearance. The centre of the disc bears short thick rod like polar thread.
\end{abstract}

Keywords: Dog louse, Egg morphology, Phthirapteran egg

\section{INTRODUCTION}

Phthirapteran eggshells often exhibit distinctive external chorionic morphological features. Different workers have provided information on the egg morphology of selected species from time to time. However, detailed SEM studies on eggs of few species have been given by selected workers (Balter, 1968a, b; Bilinski and Jankowska, 1987; Saxena et al., 2000; Castro et al., 1996; Zawadzka et al., 1997; Gupta et al., 2004, 2008 (In press); Beg et al., 2004 and Kumar et al., 2003, 2007). However, a look on literature indicates that eggshell of dog louse, Heterodoxus spiniger has not been studied by previous workers. In present contribution, an attempt has been made to describe the external features of the eggshell of an amblyceran species, Heterodoxus spiniger occurring on dog, Canis familiaris.

\section{METHODOLOGY}

Freshly laid eggs were obtained from the infested dogs. Hair bearing eggs were gently cut from host body and subjected to SEM. For SEM studies, eggs were fixed in $2.5 \%$ gluteraldehyde and passed through $0.2 \mathrm{M}$ phosphate buffer, dehydrated, arranged on aluminium stubs (covered with double sided cellotape), gold coated and examined under SEM (Mode Leo 435 VP SEM).

\section{RESULTS AND DISCUSSION}

The eggshell of $H$. spiniger is a miniature rice-grain like structure (measuring $0.80 \mathrm{~mm}$ to $0.82 \mathrm{~mm}$ in length) in appearance (Figs. 1,2). The eggs are principally laid on abdomen, breast and back region. They are glued to the hair laterally. Freshly laid egg is pearly white in appearance and start turning yellowish from $3^{\text {rd }}$ day. The egg mouth is covered with a flat disc like operculum. The apical end of opercular rim bears a row of 13-14 micropyles, arranged in more or less circular row. The micropyles are located on tall cup-shaped projections, which unite to give ridge like appearance (Figs. 3, 4). The centre of the disc bears a prominent thick rod-like structure (so called polar thread) (measuring $0.16 \mathrm{~mm}$ to $0.17 \mathrm{~mm}$ in length).

The polar thread appears to be made up of 2 filaments, which are intertwined together to form single thread. The tip of the polar thread generally remains curved. The eggshell chorion bears peculiar rectangular/ pentagonal scutes (scale like structure), arranged in rows obliquely on the eggshell (Fig. 5). The eggshell contains nearly 2022 oblique rows of such scutes. Most of the scutes present on the eggshell hang outwards (giving appearance of spines) in the lateral view. Presence of apophyses (bristle like structure) on the eggshell has not been noted. The nature of stigma (occurring at the posterior end of the eggshell) remained obscured.

Survey of literature indicates that the markings/ sculpturings present on the egg cases of phthirapteran species are species specific. Balter (1968a, b) has indicated the role of egg morphology as a guide to louse taxonomy. Microtopography of eggshells of 30 phthirapteran species infesting 15 avian hosts has been studied, so far (Balter, 1968 a, b; Bilinski and Jankowska, 1987; Saxena et al., 2000; Zawadzka et al., 1997; Beg et al., 2004; Kumar et al., 2003, 2007 and Gupta et al., 2004, 2008, in press). Furthermore, information on the nature of eggshells of selected mammalian phthirapterans (Trimenopon hispidum, Gyropus ovalis, Gliricola porcelli, Pterophithirus imitans, some species of Hoploplura, 3 species of Bovicola, 4 species of Linognathus and 2 species of Haematopinus) has become available (Castro et al., 1991; Castro et al., 1996; Kumar et al., 2003 and 
Kumar et al., 2004). Available literature indicates that eggshell of dog louse, $H$. spiniger deserved investigation. Present studies show that the eggshell of $H$. spiniger exhibits certain distinctive features i.e. presence of scale like markings (in oblique rows), occurrence of micropyles on tall cup like structures (joined together to make a thick ridge as opercular disc) and also a distinct polar thread, which provide it fascinating look. Further studies on the

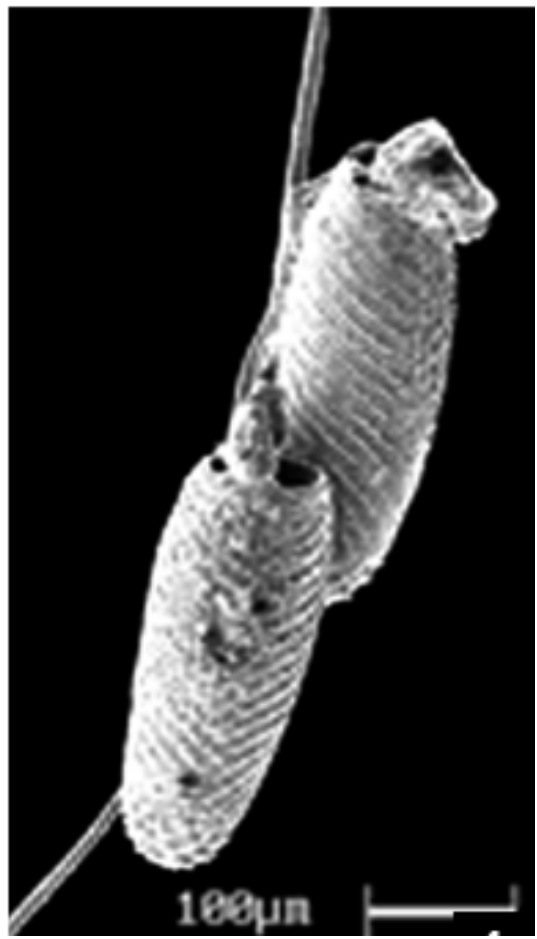

Fig. 1. SEM photograph of two deoperculated eggshell (adhering to hair) of $H$. spiniger, $\mathrm{X} 76$. eggshells of different phthirapteran species occurring on diverse mammalian hosts may provide more information on the eggshell architecture of Phthiraptera.

\section{ACKNOWLEDGMENT}

The authors are thankful to the Principal, Govt Raza P. G. College, Rampur and Principal, Govt. P. G. College, Kotdwara for laboratory facilities.

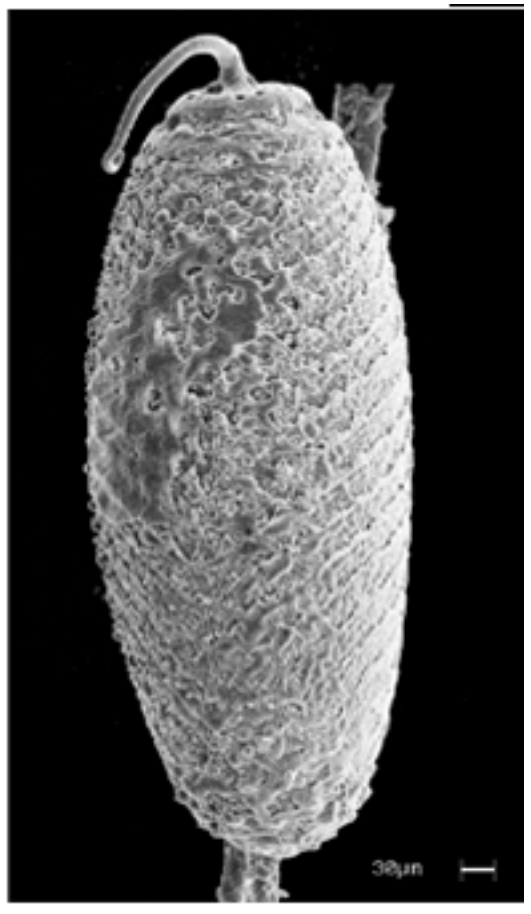

Fig. 2. SEM photograph of an operculated egg of H. spiniger, $\mathrm{X} 123$.

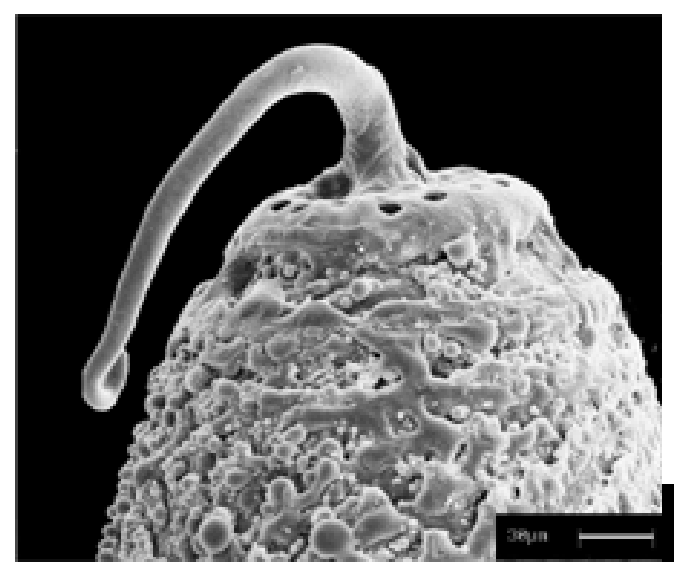

Fig. 3. Enlarged view of anterior end of the eggshell of $H$. spiniger showing the nature of opercular disc and the polar thread, X 338 . 


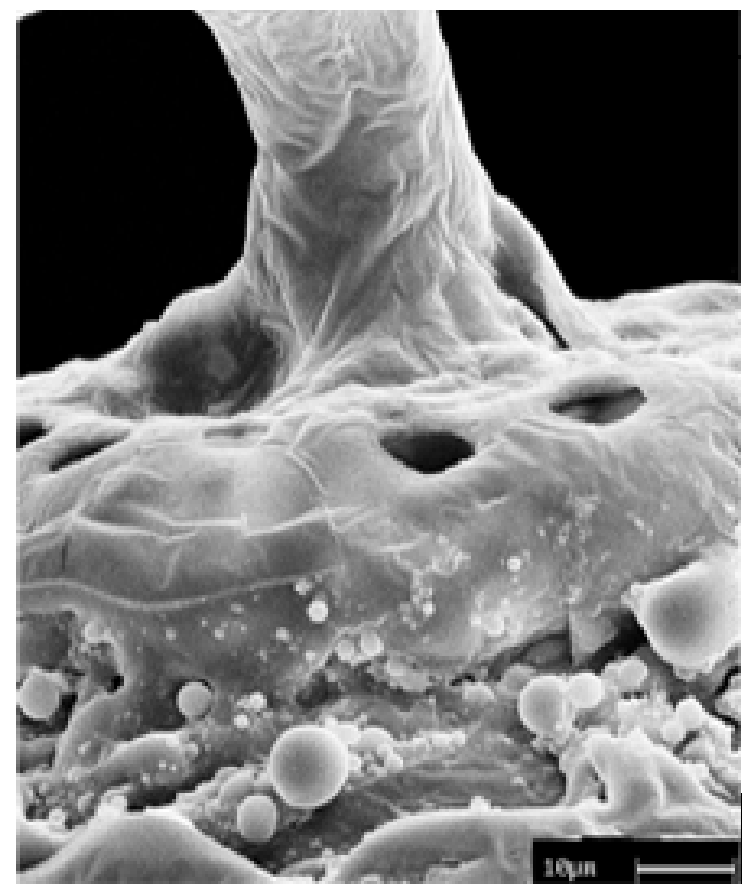

Fig. 4. Enlarged view of the opercular disc of $H$. spiniger showing the nature of micropyle, X 1000.

\section{REFERENCES}

Balter, R.S. (1968a). Lice egg morphology as a guide to louse taxonomy. Medical Biology (London), 18: 94-95.

Balter, R.S. (1968b). The microtopography of avian lice eggs. Medical Biology (London), 18: 166-179.

Beg, S., Singh, S.K., Kumar, S., Gupta, N. and Saxena. A.K. (2004). Nature of the eggshell of phthirapteran ectoparsites infesting house crows. Rivista di Parasitologia, 1: 41-49.

Bilinski, S.M. and Jankowska, W. (1987). Oogenesis in the bird louse (Eomenacanthus stramineus) (Insecta, Mallophaga). I. General description and structure of the egg capsule. Zoologische Jehruberg Anatomische, 116: 1-12.

Castro, D.D.C., Cicchino, A., and Lareschi., M. (1991). A comparative study of the external chorionic architechure of the eggs of some neotropical species of the genus Hoplopleura Enderlain, 1904 (Phthiraptera : Anoplura). Revista Brasileria de Entomology, 35 (4) : 663-669.

Castro, D.D.C., Cicchino, A. and Lareschi., M. (1996). Morfologia corionica de lose huevos de Phthiraptera (Psocodea) parasitos de Cavia pamparum Thomas, 1917 (Rodentia, Caviidae). Revista Brasileria de Entomology, 40 : 211-220.

Gupta, N., Kumar, S., Saxena, A.K., and Bisht, K.L. (2004). Aspects of oviposition of an ischnoceran (Brueelia sp.) and an amblyceran (Myrsidea amandava) lice (Phthiraptera). Proceedings of National Seminar on Zoology and Human Welfare, Allahabad, 204-210.

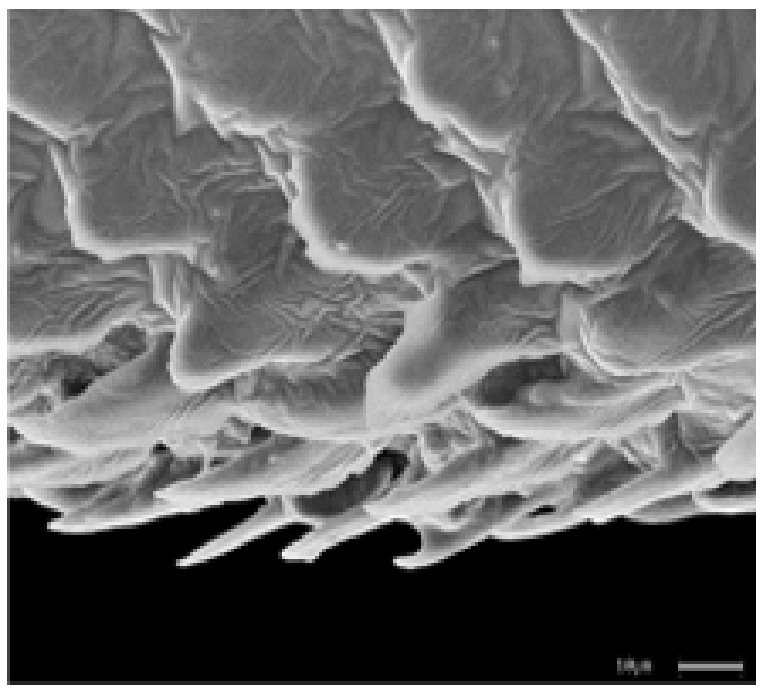

Fig. 5. Enlarged view of the chorion of the eggshell of $H$. spiniger showing the nature of sculpturings, X 1000.

Gupta, N., Khan, V., Kumar, S., Saxena, S., Rashmi, A. and Saxena, A.K. (2008). Egg shell morphology of selected Indian bird lice. (Phthiraptera:Amblycera, Ischnocera). Entomological News. (In press).

Kumar, A., Kumar, A., Kumar, S., Singh, S.K. and Saxena, A.K. (2003). Egg structure of five phthirapteran species infesting sheep and goats. Journal of Parasitology and Applied Animal Biology. 12: 25-34.

Kumar, S., Gupta, N., Singh, S.K., Singh, D.K. and Saxena, A.K. (2004). Studies on the egg morphology of four mammalian phthiraptera. The Annals of Medical Entomology, 14 (1 and 2): 10-16.

Kumar, S., Gupta, N. and Saxena, A. K. (2007). Microtopography of the eggs of two poultry lice. Indian Veterinary Journal, 84: 578-580.

Saxena, A.K., Singh, S.K., Kumar, A., Surman and Badola, S. (2000). SEM studies on the microtopography of eggs of four pigeon lice (Phthiraptera, Insecta). Rivista di Parassitologia, 3: 351-358.

Zawadzka, M., Jankowska, W. and Bilinski, S. M. (1997). Eggshells of mallophagans and anoplurans (Insecta: Phthiraptera): morphogenesis of specialized regions and the relation of F-actin cytoskeleton of follicular calle. Tissue and Cell, 29:665-673. 